Кравченко М.Ф., д-р техн. наук, проф. Піддубний В.А., д-р техн. наук, проф.

Рибчук Л.А., acn.

Київський національний торговельно-економічний університет

м. Київ, Україна

Google Scholar https://scholar.google.com.ua/citations?user=2PSlzT8AAAAJ\&hl=ru https://scholar.google.com.ua/citations? user $=$ cOllVvIAAAAJ\&hl=en

\title{
АДГЕЗІЯ ТА КОГЕЗІЯ ЦУКРОВИХ ПАСТ 3 МОЛОЧНОЮ СИРОВАТКОЮ СУХОЮ ДЕМІНЕРАЛІЗОВАНОЮ
}

У виробництві харчових продуктів поверхневі властивості проявляються найчастіше під час адгезійно-когезійної взаємодії виробів iз поверхнею матеріалу апарата чи машини. При цьому, певною мірою, спостерігається липкість продукту, що виявляється у здатності прилипання продукту до поверхні стрічки транспортера, робочого органу чи іншої поверхні машини або апарата, і впливає на витрати енергії при виробництві харчових продуктів та їхню якість. Крім того, липкість, у деяких випадках, може бути об'єктивним показником якості продукту. Недостатня липкість може вплинути на технологічні процеси перемішування, штампування, формування виробів, що $\epsilon$ важливим для виробництва цукрових паст та виготовлення оздоблювальних напівфабрикатів 3 них.

Зовсім не вивченою є адгезія цукрових паст, виготовлених за традиційною технологією. 3 метою розробки нових видів цукрових паст необхідно дослідити зазначену характеристику.

Для регулювання консистенції цукрових паст вітчизняного виробництва запропоновано, зокрема, частку цукрової пудри замінювати на молочну сироватку суху демінералізовану (МССД).

Цукрові пасти є складними структурованими системами, що поєднують властивості пружних, пластичних і в'язких тіл. Адгезія пружно-пластичних паст реалізується на межі розділу двох твердих тіл. Пружно-пластичні тіла мають аномальну в'язкість, яка змінюється залежно від напруги зсуву, властивостей маси та інших факторів. Причина мінливості в'язкості полягає в особливостях структури пружно-пластичних тіл [1,2]. 
Дослідження поверхневих структурно-механічних властивостей цукрових паст з МССД контрольних і досліджуваних зразків проведено на динамометрі MIG-1.3 методом нормального відриву [3].

Досліджено показники адгезійно-когезійної взаємодії цукрових паст із додавання МССД. Збільшення концентрації сироватки до 50\% у складі цукрових паст збільшує показники міцності адгезії майже у 2.5 рази порівняно з контролем. На показники міцності адгезії суттєво впливає час контакту лише до 20-ї секунди, далі адгезія є стабільною.

Адгезію супроводжують явища, які характеризують об'ємні властивості харчових мас та істотно впливають на адгезійну взаємодію компонентів пасти. Вплив об'ємних властивостей харчових мас на поверхневі властивості можна простежити, розглядаючи співвідношення адгезії і когезії $[1,2]$.

При адгезії спостерігається межа розділу фаз, для когезії подібна межа відсутня. У цьому одна 3 характерних особливостей когезії, іiі принципова відмінність від адгезії [1,2].

Встановлено мінімальний час контакту, коли спостерігається явище когезії для цукрових паст з МССД. У результаті проведених досліджень визначено, що зі збільшенням концентрації МССД до $50 \%$, когезія спостерігається вже на 7-й секунді, а це майже у 2 рази швидше порівняно 3 контрольним зразком. Подібна тенденція спостерігається і для паст з концентрацією МССД 30 \%, проте як для 20 \% концентрації МССД когезія спостерігається на 18-й секунді, що майже на 5 с пізніше порівняно 3 контролем. Отже, можна зробити висновок, що зі збільшенням конценцентрації МССД суттєво зростає міцність на розрив (когезія), майже у 2.3 рази порівняно 3 контролем.

Міцність адгезії контрольного зразку зі збільшенням часу контакту з повітрям повільно зменшується і на 30 с зникає. У дослідних зразках цукрових паст з вмістом МССД 20 \%, 30 \% і 50 \%, адгезія спостерігається навіть на 90 с контакту з повітрям. Дослідження показників міцності адгезії після підсихання цукрової пасти 3 МССД 2-90 с із часом контакту 2 с дали можливість встановити, що із підвищенням концентрації МССД збільшується час роботи 3 пастою, що $є$ важливим при оформленні кондитерських виробів ручним способом.

\section{Спісок бібліографічних посилань}

1. Черевко О. І., Михайлов В. М., Маяк В. І., Маяк О. А. Реологія в процесах виробництва харчових продуктів : навч. посіб. Харків. держ. ун-т харчування та торгівлі. Харків : ХДУХТ, 2014. 244 с. 
2. Муратова Е. И., Смолихина П. М. Реология кондитерских масс : монография. Тамбов : Изд-во ФГБОУ ВПО «ТГТУ», 2013. 188 с.

3. Шаповал С. Л., Романенко Р. П., Форостяна Н. П. Діагностика фізичних властивостей харчових продуктів : монографія. Київ : Київ нац. торг-екон. ун-т. 2017. 192 с. 